\title{
Clinton puts freeze on US science budget
}

Washington. The Clinton administration presented a science and technology budget proposal to Congress on Monday which seeks to boost basic research in the universities and pursue technology programmes favoured by the president, while pursuing both goals within tight fiscal constraints.

The White House proposal for the 1996 fiscal year - which begins on October 1 seeks to transfer $\$ 1$ billion from military to civil research programmes within an overall science and technology package that is frozen at this year's level of $\$ 73$ billion. Once inflation is taken into account, the proposals would result in a real cut of about 3 per cent in US government spending on research and development.

But the package is widely seen as less significant than Clinton's budget proposals for the previous two years, as the new Republican majorities in both houses of Congress are likely to use their power to change it almost beyond recognition.

Clinton announced no specific programme cuts in the science budget apart from the cancellation of the proposed Advanced Neutron Source (see right).

The administration stood by its plans significantly to increase spending in 1996 on selected technology programmes, including the Advanced Technology Programme and the Partnership for a New Generation of Vehicles (PNGV). "This is no time to waver on our commitment to these programmes," says Jack Gibbons, the President's science advisor.

Despite the freeze in the science and technology budget, no real attempt has been made to reach common ground with Congress by trimming programmes which Congress is preparing to oppose. That approach

\section{NSF: Research grants get 8 per cent boost}

Washington. The National Science Foundation (NSF), the main source of non-biomedical university research in the United States, wants to increase such funding by 7.6 per cent next year, despite tight budget constraints.

The Clinton administration is proposing that the total NSF budget should grow by 3 per cent to $\$ 3.36$ billion in 1996 - the lowest rate proposed by any administration in recent years. But by cutting back on education and the construction of research facilities, the agency proposes to boost its research grant funding by $\$ 170$ million to $\$ 2.45$ billion.

The budget proposal reflects the usual pattern of NSF's relationship with Congress: the agency tries to focus on its central task of awarding research grants, and Congress then insists on distributing more of its money to build scientific facilities, buy research equipment and boost education. reflected the overall budget proposal, which avoided specifying budget cuts and, critics says, would allow the US budget deficit to grow further. Many observers say that President Clinton, having won no political credit for last year's deficit reduction, declined to repeat the error. $\mathrm{He}$ intends to stick with his programmes, and to ensure that, if painful cuts come this year, the Republican Congress takes the blame.
Gibbons: need to face 'tough times'

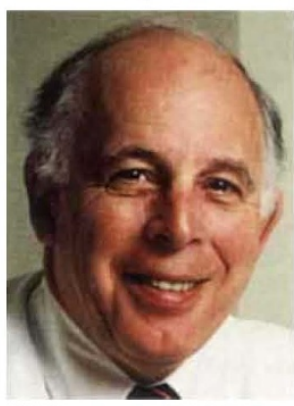

"What you see is a re-ordering of priorities," Gibbons said on Monday. "This is a budget that emphasizes the basics of science and technology." By slowing down invest-
Washington. The US Department of Energy announced on Monday that it is terminating work on the Advanced Neutron Source (ANS), planned to have been built at Oak Ridge National Laboratory, Tennessee. But it but failed to specify any of $\$ 1.2$ billion in cuts in applied research which it has promised to make over the next five years.

The department also announced a new, $\$ 100$ million programme - known as the Scientific Facilities Initiative - aimed at improving the access of university and industrial researchers to a wide range of synchrotrons and other facilities.

The new initiative is planned to come

Last year, for example, Congress approved \$250 million for NSF facilities; the budget proposal rescinds half of that, and proposes just $\$ 100$ million for facilities next year. The administration is also proposing to make a sharp cut in funding for major research equipment - reducing this from $\$ 126$ million to $\$ 70$ million - and a 2 per cent cut in the NSF's $\$ 600$ million science education budget.

The boost to research funding is distributed evenly across disciplines, although the mathematical and physical sciences (up 8.3 per cent) and social sciences (up 8.0 per cent) do slightly better than others. Most of the "strategic" research areas favoured by the previous Democrat-controlled Congress are listed for a smallerthan-average increase. But the foundation's director, Neal Lane, says that almost two-thirds of NSF-supported research is now defined as "strategic."

C. $\mathbf{M}$. ment in facilities, as well as in military research and development, the administration says it will be able to expand spending on all basic research by 3.5 per cent to $\$ 14.5$ billion, and on university research by 7 per cent, to $\$ 12.5$ billion.

Gibbons said that key areas of spending in the budget included more money for multi-agency partnerships with industry, such as the PNGV, more health and environmental research, and a leaner approach to space exploration at NASA

Conceding that, once inflation is taken into account, the frozen overall budget figure represents a real budget cut, Gibbons said it was important to remember that the administration was facing "tough times", and that no part of the budget was going to escape scrutiny. "Some programmes are up," he said. "This proposal puts a bottom line on the importance which the president puts in these investments."

Colin Macilwain

\section{DoE: neutron source to be axed}

from an increase in the department's spending on "fundamental science" from \$2.7 billion to $\$ 2.8$ billion.

The budget published by DoE said that half of this increase - $\$ 50$ million - is to be saved through unspecified 'Galvin task force reductions'. But the task force, which reported last week on the future of the energy department laboratories (see page 463), did not suggest any ways of saving money at the laboratories in the short term. "I don't know where that number comes from," Martha Krebs, director of the Office of Energy Research at DoE, said in Washington on Monday.

The DoE budget proposes a substantial expansion in spending on high energy physics, from $\$ 642$ million to $\$ 686$ million, as well as an increase in basic energy sciences from \$734 million to \$811 million. Most of both these increases would come from money that is being allocated to the Scientific Facilities Initiative.

Hazel O'Leary, the energy secretary, said that the increases "would put high energy physics back on course" after the cancellation of the superconducting supercollider in 1993, and "help to get industry and the universities into our tremendously valuable facilities."

Despite intensifying calls for the abolition of the Department of Energy, the administration plans to increase the department's total budget next year from $\$ 17.5$ billion to $\$ 17.8$ billion. O'Leary - standing in front of a cheque for $\$ 14.1$ billion made out to the US taxpayer - said that none of the savings that have been promised can be delivered in FY96. Congress is likely to view matters differently. 